\title{
A Practical Exploration of the Training of Foreign Language Personnel
}

\section{of Agricultural Foreign Trade}

\author{
Yang Zhou, Yun-Fei Ma* \\ Tianjin Agricultural University, No.22, Jinjing Road, Tianjin 300384, China \\ esther054000@163.com \\ *Corresponding author
}

\begin{abstract}
Keywords: Export of agricultural products; Foreign language of agricultural foreign trade ; Employment trends; Talent cultivation
\end{abstract}

\begin{abstract}
In the process of agricultural internationalization, one must overcome the obstacles of language communication, in order to be in line with the international economy, and to integrate into the international economic system. In this new economic situation, a lot of foreign language personnel of agricultural foreign trade are needed. This research begins from the analysis of the problems existing in the agricultural foreign trade, analyzing the abilities and limitations of current foreign language personnel of agricultural foreign trade, and puts forward the resolution of the employment of foreign language personnel of agricultural foreign trade and method of cultivating foreign language personnel of agricultural foreign trade.
\end{abstract}

\section{The Current Situation of Chinese Agricultural Products Export}

In recent years, export trade of Chinese agricultural products has gotten very good results through efforts from all sides, but there are still many deficiencies. Taking Tianjin as an example, after the investigation on several surrounding areas of Tianjin, it is found that there are still some problems in the export quantity of agricultural products, the construction of agricultural base and international competitiveness. Although the development of agricultural industrialization in China is relatively fast, a large number of enterprises have emerged in the export trade of agricultural products ${ }^{[1]}$. However, in order to achieve win-win situation of agricultural foreign trade, the country must improve its international competitiveness and cultivate agricultural foreign trade personnel. According to the investigation into several Tianjin predominantly agricultural regions, English pragmatic abilities of the cadres and enterprise staff are relatively weak, and their awareness of English learning is not strong. What's more, these regions lack interdisciplinary talents who know both agricultural technology and can skillfully use foreign language to negotiate in foreign trade. Most farmers are to support their family and reduce their family burden by manual labor. Even if some families have some farming techniques those are already behind the times. In addition, they know very little about the objective rules of the growth of crops except for some traditional experience. And to some extent they ignore the restriction of land, climate and other natural factors, so the agricultural productivity is not very high and the quality of agricultural products is not up to the standard, which is severe restrictions on the exports of agricultural products ${ }^{[2]}$. The most important reason for these problems is that the rural foreign language personnel working in foreign trade are mainly local agricultural and technical personnel. Their overall foreign language application level, comprehensive ability, the accuracy and standardization of the foreign trade are not quite high. These problems have remained for a long time and these should be timely solved. 
In recent years, the central government keeps on making policies to support agriculture aiming at raising the income of farmers and accelerating the pace of the construction of a new socialist countryside, so the rural practitioners are requested higher level of knowledge and professional qualities. The administrative department of every village can set consultation institution for farmers, hiring some experts to guide the farmers professionally. Some volunteers with specialized knowledge are also needed to help them solve the problems about the export trade and translate some English instructions of imported pesticide. The government needs to cultivate professional foreign language talents to serve the development of internationalized agriculture.

\section{The Ability and Shortage of Foreign Language Personnel of Agricultural Foreign Trade}

With the rapid development of economy, the demand of foreign language personnel is increasing. The ability, knowledge and overall quality of foreign language personnel directly affect the international trade competitive position of China, which is an urgent practical problem. Recently, an increasing number of China's export trade of agricultural products leads to continuous occurrence of a variety of economic and legal disputes. Due to the scarcity of professional personnel, some disputes and misunderstanding cannot be resolved in time, which brings negative impacts on China's economic and foreign exchange. According to the characteristics of export-oriented economic development, it is not hard to see that China's foreign language training still cannot catch up with the pace of the development of reality ${ }^{[3]}$.

The demand of foreign language personnel has presented the trend of diversification in modern society, so single foreign language or trade personnel has been unable to meet the needs of the development of modern market economy. Foreign language personnel of agricultural foreign trade should be compound talents with professional foreign language skills, foreign trade knowledge, cultural knowledge and communication exchange skills ${ }^{[4]}$. First of all, professional foreign language knowledge is not only to meet the basic requirements of the market economy and foreign trade, but also the basis for the training of foreign language personnel of foreign trade. The training conditions of foreign language personnel and employment market information show that the foreign language teaching quality has not been improved. There are also some problems with the training of foreign language personnel in some universities such as: the lack of foreign language colleges and universities, lack of high-end foreign language talents, lack of compound foreign language talents and the poor foreign language teaching environment. In addition, the cultivation of foreign language personnel and enterprises demand are contradictory. They value education, belittle ability; pay attention to the introduction of new employees, ignore the cultivation; focus on constraint, despise motivation.

Through the questionnaire survey in the major universities, many university students have passed the foreign language level examination, but when they come across the basic knowledge and vocabulary of agriculture they do not know how to express in foreign language. Also, there will be many mistakes in the translation of foreign languages into Chinese. Therefore, it is the primary task to cultivate foreign language personnel of agricultural foreign trade to meet the sore need of China's modern agricultural development.

\section{Resolution of the Employment of Foreign Language Personnel of Agricultural Foreign Trade}

Although China is an agricultural country, most graduates generally think that the salary and benefits of agricultural work are not high, and working conditions are tough and risk is considerable; 
and they always hold the wrong idea that "agriculture is farming”, "agriculture is to deal with land”, which makes most of the graduates refuse to be engaged in agriculture-related career. Even if they apply to agricultural university, they do that not out of the passion for agriculture and their professional thinking is not stable. In order to deal with this kind of employment trends the government should encourage and support students' flexible and self employment in grass-roots units. The local governments should provide corresponding personnel and labor security agency service and preferential taxation policies for graduates who are engaged in agricultural self-employed entrepreneurial career, and provide living allowance for the graduates working in rural or backward units. The market allocation of talent should be strengthened and well-organized. The employers should remove prejudice and correctly treat the students engaged in the agriculture, and provide suitable jobs for them combining with their own needs and do not keep "agriculture” a thousand miles away.

Schools should carry out active and effective ideological education guiding students to establish a correct outlook on world, life and values, set foreign language courses of agricultural foreign trade, guide students to carry out all kinds of social activities, and construct school-enterprise cooperation practice teaching mode. University students should be encouraged to work at the basic level of employment. Schools should organize employment guidance lectures for students and invite successful people in the workplace to introduce employment policy and experience. These measures are apt to make the graduates work in the grassroots units positively and actively and get into the society spiritedly.

Students should have a clear understanding of their employment situation and an objective evaluation on themselves, and timely adjust themselves to the latest employment trend. When they are at school, they should keep improving themselves and train themselves to adapt to the society and future job through social practice; they should cherish every employment opportunity to accumulate experience and continuously improve their professional skills and comprehensive qualities. Through the effort of administrations, schools and students, the requirements of high-level and high-quality foreign language personnel of agricultural foreign trade can be met.

\section{The Method of Cultivating Foreign Language Personnel of Agricultural Foreign Trade}

Although the scale of Chinese foreign language education is large, foreign language personnel who can serve the internationalized agriculture and agricultural foreign trade are not enough. One of the reasons for this is that the education concept and approach are relatively backward. The training pertinence of foreign language personnel of agricultural foreign trade is not strong. In order to cultivate excellent foreign language personnel of agricultural foreign trade, the training program needs to be improved further.

Universities should pay attention to cultivate students' creative spirit and ability, independent thinking and learning ability and allow the students to develop individually. Foreign language teaching should not only be confined to the classroom and Chinese foreign language teachers, and more foreign teachers should be hired in order to provide more opportunities for the students to contact with native speakers. The use of multimedia teaching methods is to create a new and diversified learning environment to improve students’ language skills and innovation ability ${ }^{[5]}$. Language is a kind of tool for communication not the curriculum of pure knowledge, so classroom teaching and extra-curricular activities should combine organically. In addition to that, carrying out practical training can make students experience the real scenes in the workplace and truly understand the enterprise's production process, become familiar with enterprise system and culture, 
and learn how to communicate with the people around so as to adapt to the social needs better and recognize their value ${ }^{[6]}$. Excellent command of foreign language is one of the essential abilities for university students entering the international arena. So effective foreign language training is very important. The schools should adjust the training content and methods timely. Corresponding regulations should be laid down in the training process. Cooperation between universities and enterprises is quite necessary. Universities can invite excellent employees of agricultural foreign trade enterprises to give lectures to students. Enterprises can also employ foreign trade English teachers of well-known institutions to train their staff.

According to the target needs analysis and employer interviews, the market attaches much importance to employees' practical skills and communication competencies. Therefore, the education objective of foreign language personnel of agricultural foreign trade is to not only teach students basic knowledge of the agricultural foreign trade field, but also to teach them how to use English for effective agricultural foreign trade communication and how to deal with agricultural foreign trade activities flexibly ${ }^{[7]}$. In times of increased global interdependence, producing interculturally competent citizens who can engage in informed, ethical decision-making when confronted with problems that involve a diversity of perspectives is becoming an urgent educational priority ${ }^{[8]}$.

\section{Summary}

With the continuous increase in China's international trade of agricultural products, foreign language personnel of agricultural foreign trade play a more and more important role in international agricultural trade. Foreign trade talents are not only a bridge of cultural exchanges between countries, but also tie of expanding import and export trade. Comparatively speaking, employment market of foreign language personnel of agricultural foreign trade is still very substantial and its development direction is very extensive. Therefore, the government should train a number of foreign language personnel of agricultural foreign trade who are familiar with international free market of agricultural products to help farmers strengthen the concept of market and have more opportunities to participate in the international agricultural transactions. The government and enterprises should pay enough attention to foreign language personnel of agricultural foreign trade so that these talents can build bridges for agricultural trade exchanges between countries and lay a solid foundation for the further expansion of China's agricultural international market.

\section{Acknowledgements}

This research was financially supported by China Agricultural Association funded project: "research on the strategy of universities agricultural think tank construction from the international perspective" (PCE1401); the National Educational Science "the $12^{\text {th }}$ Five Year Plan" 2014 key project of Ministry of Education: "research and formulation of Common Chinese Framework of Reference for English level” (DIA140304).

\section{Introduction of Author:}

Zhou Yang (1993 - ), female, the Han nationality, from Tianjin. Student of College of Humanities of Tianjin Agricultural University. Research interests: Agricultural foreign trade translation.

\section{Introduction of Corresponding Author:}

Ma Yun-Fei (1977 - ), female, the Han nationality, from Tianjin. Lecturer of College of Humanities 
of Tianjin Agricultural University, master of English language and literature. Research interests: the British and American literature, English education.

\section{References:}

[1] Qijie Gao, Agricultural Extension. China Agricultural University Press, Beijing, 2003.

[2] Zitong Lin, The Management Course of Sino Foreign Joint Ventures. Fudan University Press, Shanghai, 1996.

[3] Changhong Pei, Peng Lei, et al. The Study of China's Open Economy in Post Crisis Era: Transformation of Foreign Trade Developmental Pattern and New trend of Foreign Trade and Economic Cooperation. Science and Society Literature Publishing House, Beijing, 2010.

[4] Syllabus for Foreign Language Major Teaching in Universities. Foreign Language Teaching and Research Press, Beijing, 2000.

[5] Advanced Teaching Foreign Language Major Teaching Instructing committee English group. Evaluation of Business English Majors Courses [J]. Foreign Language and Foreign Language Teaching, Beijing, 2001, (4): 33-35.

[6] Longjiang Chen, China's agricultural products export environment in the financial crisis: status quo and trends [J]. Agricultural Economic Problems, 2010, (4): 94-100.

[7] Zhang Qi. Needs-Based Analysis on Curriculum Design of Undergraduate Business English Program-A Case Study of SEIB in GDUFS [D]. Guangzhou: Guangdong University of Foreign Studies, 2013.

[8] Information on http://mp.weixin.qq.com/s?_biz=MjM5MT3OTY1NQ==\&mid=2653494525\&id x=1\&sn=c53305904a15ff862a4ade97288dfcf1\&scene=23\&srcid=0430wx46tslcL5BV6QjTvmXa\#r d 